\title{
How sensitive is the recovery of stratospheric ozone to changes in concentrations of very short-lived bromocarbons?
}

\author{
X. Yang ${ }^{1,2, *}$, N. L. Abraham ${ }^{1,2}$, A. T. Archibald ${ }^{1,2}$, P. Braesicke ${ }^{1,2, * *}$, J. Keeble ${ }^{2}$, P. J. Telford ${ }^{1,2}$, N. J. Warwick ${ }^{1,2}$, and \\ J. A. Pyle ${ }^{1,2}$ \\ ${ }^{1}$ National Centre for Atmospheric Science (NCAS-Climate), Cambridge, UK \\ ${ }^{2}$ Centre for Atmospheric Science, Department of Chemistry, University of Cambridge, Cambridge, UK \\ * now at: British Antarctic Survey, Cambridge, UK \\ *** now at: Karlsruhe Institute of Technology, Institute for Meteorology and Climate Research, Karlsruhe, Germany
}

Correspondence to: X. Yang (xinyang55@bas.ac.uk)

Received: 25 February 2014 - Published in Atmos. Chem. Phys. Discuss.: 14 April 2014

Revised: 21 August 2014 - Accepted: 22 August 2014 - Published: 1 October 2014

\begin{abstract}
Naturally produced very short-lived substances (VSLS) account for almost a quarter of the current stratospheric inorganic bromine, $\mathrm{Br}_{\mathrm{y}}$. Following VSLS oxidation, bromine radicals $(\mathrm{Br}$ and $\mathrm{BrO})$ can catalytically destroy ozone. The extent to which possible increases in surface emissions or transport of these VSLS bromocarbons to the stratosphere could counteract the effect of halogen reductions under the Montreal Protocol is an important policy question. Here, by using a chemistry-climate model, UMUKCA, we investigate the impact of a hypothetical doubling (an increase of $5 \mathrm{ppt} \mathrm{Br}_{\mathrm{y}}$ ) of VSLS bromocarbons on ozone and how the resulting ozone changes depend on the background concentrations of chlorine and bromine. Our model experiments indicate that for the $5 \mathrm{ppt}$ increase in $\mathrm{Br}_{\mathrm{y}}$ from VSLS, the ozone decrease in the lowermost stratosphere of the Southern Hemisphere (SH) may reach up to $10 \%$ in the annual mean; the ozone decrease in the Northern Hemisphere (NH) is smaller (4-6\%). The largest impact on the ozone column is found in the Antarctic spring. There is a significantly larger ozone decrease following the doubling of the VSLS burden under a high stratospheric chlorine background than under a low chlorine background, indicating the importance of the inter-halogen reactions. For example, the decline in the high-latitude, lower-stratospheric ozone concentration as a function of $\mathrm{Br}_{\mathrm{y}}$ is higher by about $30-40 \%$ when stratospheric $\mathrm{Cl}_{\mathrm{y}}$ is $\sim 3 \mathrm{ppb}$ (present day), compared with $\mathrm{Cl}_{\mathrm{y}}$ of $\sim 0.8 \mathrm{ppb}$ (a pre-industrial or projected future situation). Bromine will play an important role in the future ozone layer. However, even if bromine levels from natural VSLS were to
\end{abstract}

increase significantly later this century, changes in the concentration of ozone will likely be dominated by the decrease in anthropogenic chlorine. Our calculation suggests that for a 5 pt increase in $\mathrm{Br}_{\mathrm{y}}$ from VSLS, the Antarctic ozone hole recovery date could be delayed by approximately $6-8$ years, depending on $\mathrm{Cl}_{\mathrm{y}}$ levels.

\section{Introduction}

It is now very well established that stratospheric ozone loss since the 1970s has occurred as a consequence of emissions of halogenated species into the atmosphere. These gases, the chlorofluorocarbons (CFCs) and halons, are generally long lived in the troposphere, but at sufficient altitudes in the stratosphere, they can be oxidised to liberate chlorine (as suggested by Molina and Rowland, 1974) and bromine (see Wofsy et al., 1975) atoms, which can subsequently play a role in catalytic ozone destruction. The "ozone hole" in Antarctica was reported by Farman and his colleagues in 1985 (Farman et al., 1985), and intensive field, laboratory and modelling research was soon able to demonstrate that the observed decline in polar ozone was indeed a result of ozone destruction by halogen chemistry. First investigations (for details, see the review by Solomon, 1999) focused on the role of chlorine, but subsequent research (see e.g. the observationally based study of Salawitch et al., 1988 and the modelling study of Chipperfield and Pyle, 1998) showed that coupled chlorine-bromine reactions made a substantial 
contribution to the polar loss, as first suggested by McElroy et al. (1986). Following on from the scientific understanding that anthropogenic halogens were responsible for ozone loss, the Montreal Protocol was enacted to regulate the production and consumption of ozone-depleting substances. The protocol has been a major success, and atmospheric concentrations of the regulated chlorine and bromine gases are now in decline (WMO, 2011).

Chlorine in the stratosphere arises mainly from industrial compounds, principally the CFCs, with a contribution of about $0.6 \mathrm{ppb}$ ( $\sim 20 \%$ relative to current values) from longlived, naturally occurring $\mathrm{CH}_{3} \mathrm{Cl}$ (see, for example, Harper and Hamilton, 2003). In contrast, the bromine budget of the stratosphere is less well constrained (Ko et al., 1997; Dorf et al., 2008). It is now thought that about $5 \mathrm{ppt}(\sim 20$ to $25 \%$ ) of stratospheric bromine may come from the oxidation of halocarbons with lifetimes of less than about 6 months (so-called very short-lived substances, VSLS), while the majority comes from methyl bromide and the anthropogenic halons. Thorough reviews of these halogen gases are available in the recent UNEP/WMO ozone assessment (Montzka et al., 2011), where the total stratospheric bromine concentration in 2008 is given as $22.5 \mathrm{ppt}$. In the pre-industrial era, the VSLS contribution may have been as much as $50 \%$ of the total atmospheric bromine loading. VSLS bromocarbons are mainly produced by macro- and micro-algae (Carpenter and Liss, 2000; Quack and Wallace, 2003; Yokouchi et al., 2005). $\mathrm{CHBr}_{3}$ and $\mathrm{CH}_{2} \mathrm{Br}_{2}$ are the dominant contributors to bromine VSLS species. Although their tropospheric lifetime is relatively short (a few weeks for $\mathrm{CHBr}_{3}$ and several months for $\mathrm{CH}_{2} \mathrm{Br}_{2}$ ), they can be lifted effectively through deep convective systems and transported into the upper troposphere and/or lower stratosphere (UTLS) to make a significant contribution to the total ambient bromine (Sturges et al., 2000; Yang et al., 2005; Salawitch, 2006). Being short lived, there are large uncertainties in using atmospheric concentration measurements to estimate their global fluxes and their net contribution to the stratospheric bromine (Warwick et al., 2006; Liang et al., 2010; Pyle et al., 2011; Ordóñez et al., 2012; Ziska et al., 2013; Hossaini et al., 2013). A large range of contributions to stratospheric inorganic bromine of $110 \mathrm{ppt}$ can be found in the literature (Dorf et al., 2008; Salawich et al., 2010; Schofield et al., 2011; Aschmann et al., 2011; Tegtmeier et al., 2012; Stachnik et al., 2013; Hossaini et al., 2012a). The UNEP/WMO ozone assessment of 2011 reports the value as 6(3-8) ppt (Montzka, Reimann et al., 2011).

Stratospheric inorganic chlorine has increased from preindustrial levels of $\sim 0.6 \mathrm{ppb}$ to a peak of greater than $3 \mathrm{ppb}$ in the 1990s and, under the influence of the Montreal Protocol, is decreasing and is expected to continue to decrease during this century (WMO, 2011). The sum of the concentrations of anthropogenic bromine compounds is now also declining. Under the influence of the Montreal Protocol, the stratospheric ozone layer should recover later this century.
While anthropogenic halogen loading to the stratosphere should decrease in response to the Montreal Protocol, we do not know how the concentration of the VSLS bromocarbons will change in the future. Since they are mainly produced by biochemical processes, mostly in the ocean, their emissions could change with climate, perhaps depending on sea surface temperature, on ocean $\mathrm{pH}$ or on surface wind stress (Gschwend et al., 1985; Keppler et al., 2000). We currently do not have a good enough understanding to allow confident predictions. Changes in transport to the stratosphere could also occur due to climate change. For example, Hossaini et al. (2012b) predict $0.3-1.0 \mathrm{ppt}$ increases in the direct transport of bromine source gases to the stratosphere between 2000 and 2100 under RCPs 4.5 and 8.5, while the earlier study of Dessens et al. (2009) projects a 1-2 ppt increase in total bromine in the lower stratosphere.

Bromine is about 100 times more efficient than chlorine as an ozone sink in the high-latitude lower stratosphere, with an annual average global value of around 65 (Sinnhuber et al., 2009), so any future increases in stratospheric bromine, perhaps driven by increased emissions of VSLS bromocarbon or its transport to the stratosphere, could affect stratospheric ozone recovery. Our primary aim in this paper is to explore the sensitivity of ozone recovery to changes in the concentrations of bromine in the stratosphere arising from very shortlived bromocarbons.

Gas phase and heterogeneous inter-halogen reactions involving both bromine and chlorine contribute significantly to ozone loss, so that the ozone loss due to bromine should be dependent on the chlorine concentration. A second aim of this paper is to investigate how ozone might respond to changes in VSLS loading when future stratospheric chlorine levels have declined.

To address these aims, we use the UM-UKCA chemistryclimate model. We perform a number of idealised experiments under two different stratospheric chlorine concentrations, corresponding very roughly to the present day and to the end of the twenty-first century, and three different bromine levels. The range of bromine concentrations chosen allows us to explore the sensitivity of the coupled chlorinebromine system. Each experiment is run twice, first with a VSLS contribution of 5 ppt and then with an additional increase of $5 \mathrm{ppt}$. These experiments allow us to explore how ozone loss due to short-lived bromocarbons could vary with background chlorine and bromine loading. We note that $5 \mathrm{ppt}$ would represent a large change in the contribution of shortlived bromine to the stratosphere; we reiterate that these are idealised experiments designed to explore the sensitivity of ozone recovery to hypothetical changes in bromine.

Other changes could also affect stratospheric ozone recovery (and the contribution of bromine changes to ozone recovery). Several previous studies have looked at the impact of VSLS bromocarbons on ozone trends in the recent past (e.g. Salawitch et al., 2005; Feng et al., 2007; Sinnhuber et al., 2009). They show that the effect of VSLS on 
ozone is particularly important under enhanced aerosol loading. Transient changes due to volcanic eruptions would certainly affect the trajectory of recovery, while a sustained increase in stratospheric aerosol would also lead to a general decrease in ozone and an increased role of bromine and chlorine heterogeneous processing. However, in the calculations here, aerosol loading is held constant. Climate change will also affect the recovery of stratospheric ozone, as is well known. Salawitch et al. (2005) show that, while the effect of bromine on ozone is dominated by the $\mathrm{ClO}+\mathrm{BrO}$ reaction in the lowermost stratosphere, the reaction of $\mathrm{BrO}+\mathrm{HO}_{2}$ becomes increasingly important with increasing VSLS. Thus, any change in $\mathrm{HO}_{2}$ in the future could potentially affect the estimation of the ozone impact from these changes in halogens. We do not deal with this in detail here, although we do mention in Sect. 3 possible changes in the flux through the $\mathrm{BrO}+\mathrm{HO}_{2}$ reaction under climate change.

The model and the experimental set-up are described in more detail in Sect. 2. The model results are presented in Sect. 3. A concluding discussion is found in Sect. 4.

\section{Model and experiments}

UM-UKCA is a chemistry-climate model; its dynamical core is Met Office Unified Model (UM) version 7.3 running in the HadGEM3-A configuration (similar to Hewitt et al., 2011). The detailed chemistry scheme for the troposphere and stratosphere, CheST, combines the schemes described by Morgenstern et al. (2009) and O'Connor et al. (2014), and was further updated with tropospheric bromine chemistry based on our work in the pTOMCAT chemistry transport model (Yang et al., 2005, 2010). The stratospheric halogen scheme is improved by introducing a number of heterogeneous reactions to stratospheric particles (polar stratospheric clouds (PSCs) and sulfate aerosol) to account for inter-halogen (chlorine and bromine) reactivation, as in our recent study (Braesicke et al., 2013). The model's horizontal resolution is $3.75^{\circ}$ in longitude and $2.5^{\circ}$ in latitude on an Arakawa $\mathrm{C}$ grid. A hybrid sigma geometric height coordinate is used to resolve the vertical range from the surface to $\sim 84 \mathrm{~km}$ with 60 levels. All experiments are performed for year 2000 boundary conditions with prescribed monthly sea surface temperatures (SSTs) and sea ice conditions. The radiative species concentrations for $\mathrm{CO}_{2}, \mathrm{~N}_{2} \mathrm{O}$ and $\mathrm{CH}_{4}$ are taken for the year 2000; ozone is calculated interactively. Apart from the halocarbons (e.g. CFCs, $\mathrm{CH}_{3} \mathrm{Br}$ ), chemical emissions are for the present day. The sulfate aerosol field is a monthly climatology. PSCs and ice particles are calculated online based on water vapour fields and temperatures. To get significant results, each of the experiments was performed as a 40-year time-slice integration, with the first 20 years as spin-up and the last 20 years for analysis.

For the VSLS bromocarbons in the model, we have introduced tracers for five additional species $\left(\mathrm{CHBr}_{3}, \mathrm{CH}_{2} \mathrm{Br}_{2}\right.$,
$\mathrm{CH}_{2} \mathrm{BrCl}, \mathrm{CHBr}_{2} \mathrm{Cl}$ and $\mathrm{CHBrCl}_{2}$ ), with emissions based on the original work (scenario 5) of Warwick et al. (2006), except for emissions of $\mathrm{CH}_{2} \mathrm{Br}_{2}$, which were updated to $57 \mathrm{Gg} \mathrm{yr}^{-1}, 50 \%$ of the original flux, but which are now much more in accordance with Liang et al. (2010) and Ordóñez et al. (2012). Our updated fluxes provide $\sim 5$ ppt of inorganic bromine to the stratosphere.

We have six base experiments, using two different stratospheric chlorine loadings and three different stratospheric bromine loadings designed to cover a range of past, present and possible future halogen loadings. We chose stratospheric chlorine levels of $\sim 0.8$ and $\sim 3 \mathrm{ppb}$, achieved by applying fixed concentrations in the model's lowest layer for the major chlorine species, $\mathrm{CFCs}, \mathrm{CH}_{3} \mathrm{Cl}$ and $\mathrm{CCl}_{4}$ (from the $\mathrm{A} 1$ scenario of the WMO, 2011). $3 \mathrm{ppb}$ is roughly a presentday stratospheric chlorine loading. The low chlorine level of $0.8 \mathrm{ppb}$ represents both a pre-industrial chlorine value (when $\mathrm{CH}_{3} \mathrm{Cl}$ at $0.6 \mathrm{ppb}$ was the major chlorine carrier), as well as a likely chlorine level towards the end of the century, on a Montreal Protocol trajectory towards "recovery", according to projected mitigation scenarios for 2100. For stratospheric inorganic bromine, we chose three levels of $\sim 10, \sim 15$ and $\sim 23$ ppt to represent approximately a low $(\sim$ pre-industrial era, when ice core data suggest a methyl bromide concentration of about 5 ppt; Saltzman et al., 2008), medium and high ( $\sim$ present-day) level, respectively. These values all include $\sim 5$ ppt from VSLS (as described above), with the remaining $\mathrm{Br}_{\mathrm{y}}$ coming from long-lived halons and $\mathrm{CH}_{3} \mathrm{Br}$. These values are somewhat arbitrary; our simple aim is to explore a range of $\mathrm{Br}_{\mathrm{y}}$ values and, based on them, to investigate the ozone response to perturbed VSLS bromocarbon emissions.

Our study is designed to address how changes in VSLS bromocarbons would impact stratospheric ozone against a background of changes in stratospheric chlorine and bromine loading, so each base experiment is then repeated with the VSLS bromocarbon contribution doubled, to about $10 \mathrm{ppt}$. In the next section, for each base experiment, we look at the difference in the ozone results between the $2 \times$ VSLS and $1 \times$ VSLS ( $\sim 5$ ppt increase in stratospheric $\mathrm{Br}_{y}$ ) integrations.

\section{Result and discussions}

Figure 1 shows the annual zonal mean ozone differences between pairs of runs in which the VSLS bromine contribution was increased by $5 \mathrm{ppt}$. The plots show the $2 \times$ VSLS $-1 \times$ VSLS ozone differences in percentage. The left column shows ozone changes for a low stratospheric $\mathrm{Cl}_{\mathrm{y}}$ of $0.8 \mathrm{ppb}$, representative either of a pre-industrial atmosphere or a substantial reduction in halogen loading. The right column has a $\mathrm{Cl}_{\mathrm{y}}$ of $\sim 3 \mathrm{ppb}$, roughly representative of the present day. The panels from top to bottom have, respectively, a high inorganic bromine background of $\sim 23 \mathrm{ppt}$ 


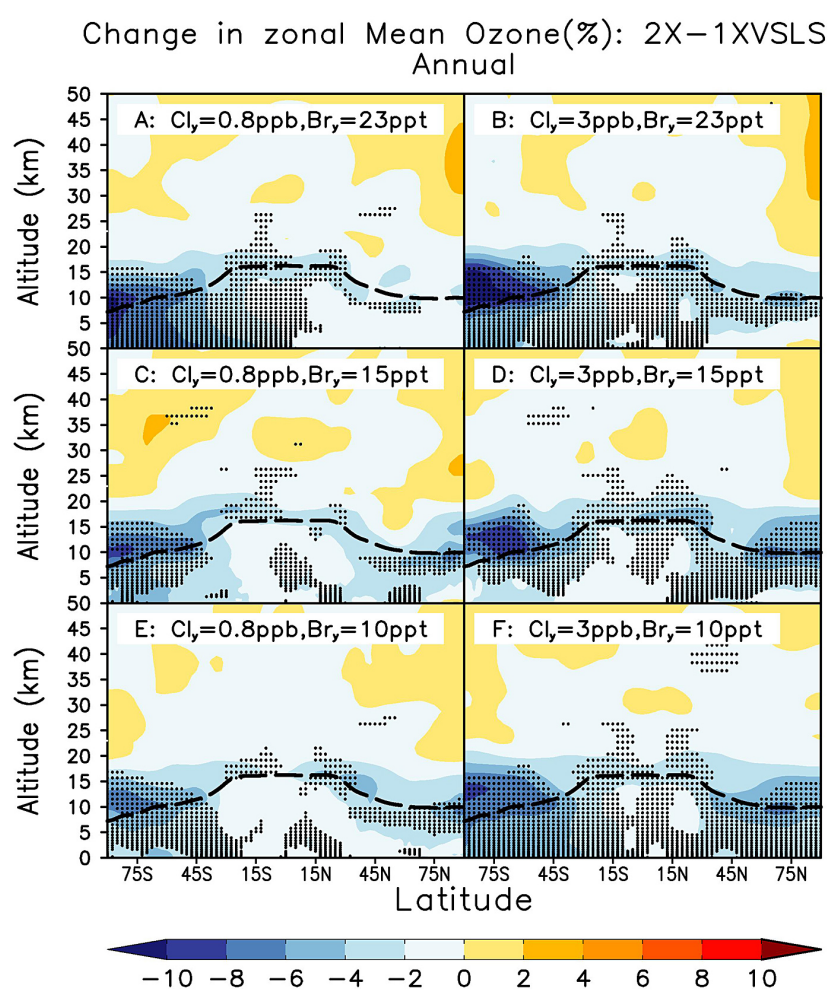

Figure 1. Relative ozone changes (in \%) arising from doubling VSL emissions under $0.8 \mathrm{ppb} \mathrm{Cl}_{\mathrm{y}}$ (left column) and $3 \mathrm{ppb} \mathrm{Cl}_{\mathrm{y}}$ (right column). The base case $\mathrm{Br}_{\mathrm{y}}$ concentrations (with $1 \times \mathrm{VSLS}$, representing $5 \mathrm{ppt}$ of the total $\mathrm{Br}_{y}$ ) increase from the bottom to the top row, as indicated in the panels. The dotted regions represent statistically significant signals on a confidence level above $95 \%$, as calculated by a student's $t$ test.

(Fig. 1a, b), 15 ppt (Fig. 1c, d), and a low bromine background of $\sim 10$ ppt (Fig. 1e, f).

For a doubled VSLS emission, with an extra $\sim 5$ ppt $\mathrm{Br}_{\mathrm{y}}$ in the stratosphere, the ozone differences in these runs are statistically significant $(P<0.05)$ (marked with dots in Fig. 1) in most of the atmosphere below $20 \mathrm{~km}$. The less significant signals above $20 \mathrm{~km}$ are likely due to the strong dynamical feedback rather than the chemical response, as addressed in a related paper by Braesicke et al. (2013). Longer runs would be required to ensure statistical significance in the middle and upper stratosphere, where the relative changes in ozone are small, and we focus here on the lowermost stratosphere, where VSLS has a more important role.

Below $20 \mathrm{~km}$ in the $\mathrm{SH}$, the largest annual mean decrease is about $10 \%$, while at the NH high latitudes, the ozone decreases by $4-6 \%$. Near the tropical tropopause, an ozone decline of $2-4 \%$ is modelled. Since the ozone concentration near the tropopause is low, these losses are small in absolute terms (less than $10 \mathrm{ppbv}$ ). In terms of the seasonal response, a maximum local ozone reduction of $\sim 20 \%$ is simulated at the SH high latitudes from spring to early summer. The sea- sonal variation in column ozone loss at the SH high latitudes is discussed below.

It is interesting to see that ozone decrease is significant in most of the troposphere, with a small deficit of less than $2 \%$ in the tropics, $2-4 \%$ at high latitudes of the $\mathrm{NH}$, and 2-6\% in the SH. In absolute terms, the ozone decline in most of the free troposphere is smaller than $2 \mathrm{ppb}$. Further experiments in which we switched off the inter-halogen heterogeneous reactions suggest that the tropical response is due to in situ tropospheric chemistry. The changes in tropospheric ozone at high latitudes, in contrast, are largely due to the transport of ozone-depleted air from the lower stratosphere.

When $\mathrm{Cl}_{\mathrm{y}}$ is $\sim 3 \mathrm{ppb}$, the maximum $\mathrm{SH}$ polar ozone decrease of about $10 \%$ shown in Fig. 1 corresponds to $\sim 100 \mathrm{ppb}$, compared with $\sim 70 \mathrm{ppb}$ for a $\mathrm{Cl}_{\mathrm{y}}$ mixing ratio of $0.8 \mathrm{ppb}$. In the $\mathrm{NH}$, the ozone decrease is about half of the magnitude simulated in the $\mathrm{SH}$.

Comparing the left and right panels in Fig. 1 for the same bromine loadings, we see a greater ozone decrease when the chlorine background is higher. Cycles involving both chlorine and bromine radicals will be more efficient at a given bromine concentration when chlorine levels are higher. To demonstrate this clearly, Fig. 2 plots the relationship between the ozone and total inorganic $\mathrm{Br}_{\mathrm{y}}$ concentrations at $\sim 15 \mathrm{~km}$ for (a) $80^{\circ} \mathrm{S}$ and (b) $80^{\circ} \mathrm{N}$ from our experiments with the different chlorine levels. We note that, in all cases, ozone decreases almost linearly with increasing $\mathrm{Br}_{\mathrm{y}}$ concentrations; straight line fits are given for each $\mathrm{Cl}_{\mathrm{y}}$ value. The gradient of the ozone decrease as a function of increasing $\mathrm{Br}_{\mathrm{y}}$ is larger by about $30-40 \%$ when $\mathrm{Cl}_{\mathrm{y}}$ is $\sim 3 \mathrm{ppb}$, compared with the $\mathrm{Cl}_{\mathrm{y}}$ of $\sim 0.8 \mathrm{ppb}$. As would be expected given the greater potential for heterogeneous chemistry, there is more ozone loss in the SH than in the $\mathrm{NH}$ under the same $\mathrm{Cl}_{\mathrm{y}}$ level.

Comparing the red and blue lines in Fig. 2a, we can see that, for a given $\mathrm{Br}_{\mathrm{y}}$ level, the ozone concentrations under a pre-industrial (or ozone-recovered) $\mathrm{Cl}_{\mathrm{y}}$ of $0.8 \mathrm{ppb}$ are $\sim 500 \mathrm{ppb}$ higher than that at the current $\mathrm{Cl}_{\mathrm{y}}$ of $\sim 3 \mathrm{ppb}$ in the SH. According to the fit lines in Fig. 2a, for a $\mathrm{Br}_{\mathrm{y}}$ increase of 20 ppt (a roughly four-fold increase of VSLS emissions), the ozone decreases are 190 (red line) and $280 \mathrm{ppb}$ (blue line), respectively, considerably less than the chlorinedriven changes, so even if bromine levels from natural VSLS were to increase very significantly later this century, changes in the concentration of ozone will likely be dominated by the recovery of anthropogenic chlorine.

We have noted above that longer runs would be required to reveal statistically significant changes in the pair-wise ozone differences in the middle and upper stratosphere shown in Fig. 1. Consequently, changes in column ozone between the different experiments can be somewhat noisy. However, spatial and temporal averaging, as well as the grouping of experiments together, can improve the statistical significance of the column ozone changes. Focusing on the importance of a $5 \mathrm{ppt} \mathrm{Br}_{\mathrm{y}}$ increase under the two different chlorine loadings, we can achieve a reasonable estimate of the difference in 
(a) at $15 \mathrm{~km}, 80^{\circ} \mathrm{S}$

(b) at $15 \mathrm{~km}, 80^{\circ} \mathrm{N}$

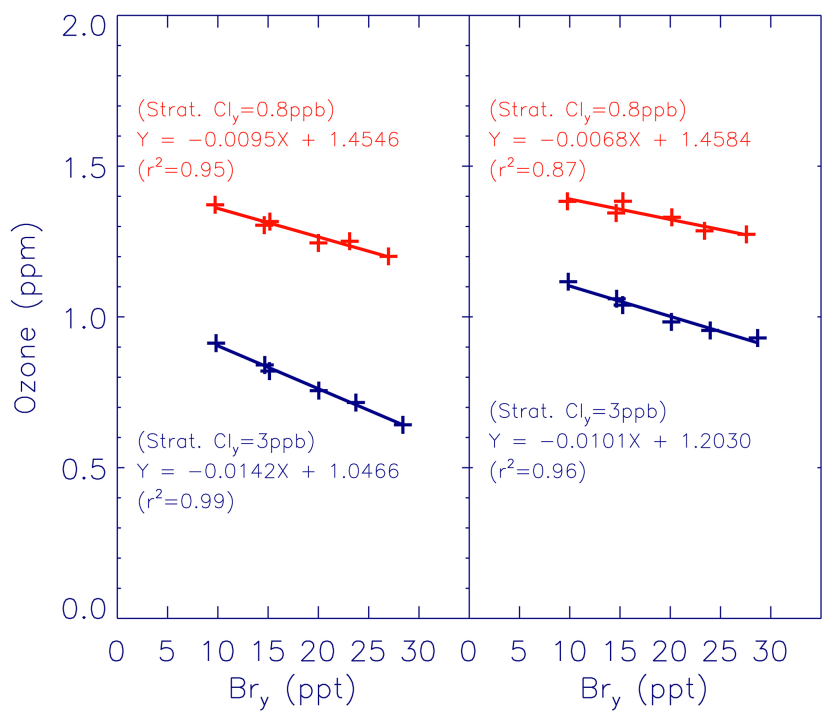

Figure 2. Relationship between stratospheric ozone concentrations and $\mathrm{Br}_{\mathrm{y}}$ at $\sim 15 \mathrm{~km}$ and (a) $80^{\circ} \mathrm{S}$ and (b) $80^{\circ} \mathrm{N}$. Straight lines have been fitted for each $\mathrm{Cl}_{\mathrm{y}}$ concentration (red: $\mathrm{Cl}_{y}=0.8 \mathrm{ppb}$; blue: $\mathrm{Cl}_{y}=3 \mathrm{ppb}$ ), and the quality of the fit is indicated by the correlation coefficient $\left(r^{2}\right)$.

column ozone by averaging the results from the three different $\mathrm{Br}_{\mathrm{y}}$ backgrounds for each of the $0.8 \mathrm{ppb}$ and $3.0 \mathrm{ppbCl}_{\mathrm{y}}$ cases, respectively.

Figure 3 shows the seasonal evolution of column ozone at high southern latitudes, plotting the average difference when VSLS bromine is increased by $5 \mathrm{ppt}$ for each of the two background chlorine loadings. Again, the relative change in ozone is higher under the higher chlorine loading. Under higher chlorine (red line), we model much lower column ozone globally and a larger ozone hole compared with the $\mathrm{Cl}_{y}=0.8 \mathrm{ppb}$ case (black line). For $3 \mathrm{ppb}$ of chlorine, a more pronounced seasonal cycle emerges, with the ozone differences peaking in Antarctic spring. In spring (October), the modelled total column ozone decrease is about $9 \mathrm{DU}$ for the $0.8 \mathrm{ppb}$ chlorine case, and about $11 \mathrm{DU}$ for the $3 \mathrm{ppb}$ case. Column differences in the Arctic are only marginally significant, at best (see Fig. 4), so we do not discuss the NH seasonal evolution.

Figure 4 shows annually averaged column ozone differences as a function of latitude. The largest reductions in the column occur at high latitudes, as expected, with a peak reduction of above $8 \mathrm{DU}$ at southern high latitudes under the high chlorine scenario (Fig. 4a), which is about $3.5 \%$ of the total column ozone (Fig. 4b). The changes in Fig. 4 are smaller at low latitudes ( $\sim 2 \mathrm{DU}$, or $\sim 1 \%)$, and appear to be relatively insensitive to the chlorine background. Note the reduced area of statistical significance in the $\mathrm{NH}$ (as indicated by the horizontal lines in Fig. 4b; see caption for details),



Figure 3. Relative change in column ozone (in \%) due to a doubling of VSLS Bry averaged over $60-90^{\circ} \mathrm{S}$. Each line represents one particular $\mathrm{Cl}_{\mathrm{y}}$ level (black open circles: $\mathrm{Cl}_{y}=0.8 \mathrm{ppb}$; red closed circles: $\mathrm{Cl}_{y}=3 \mathrm{ppb}$ ). Note that we average the ozone difference over the three different $\mathrm{Br}_{\mathrm{y}}$ concentrations for each $\mathrm{Cl}_{\mathrm{y}}$ case. The individual results for different background $\mathrm{Br}_{\mathrm{y}}$ are shown in Figs. 1 and 2 .

especially under low chlorine loading, consistent with much greater dynamical variability there.

All our integrations have used year 2000 boundary conditions, so the impact of climate change on the chemistry here has not been considered. Separate integrations looking at ozone recovery under a range of different greenhouse gas scenarios, but with constant boundary conditions for chlorine and bromine source gases (see Banerjee et al., 2014), do throw some light on possible changes in some key bromine reaction fluxes. For example, focusing just on changes in the stratosphere, the change in the flux through the reaction $\mathrm{HO}_{2}+\mathrm{BrO}$ between 2000 and 2100 under RCP8.5 is less than $10 \%$ in the lower stratosphere of high southern latitudes, where the calculated changes reported here are highest. Slightly larger changes are found in the tropical very low stratosphere, where ozone concentrations are low, and just above the tropopause at high northern latitudes, where dynamically driven variability in ozone is high. We believe that while climate change will certainly affect the impact of VSLS on ozone recovery, it will not change the general results presented here.

\section{Conclusions and discussions}

Naturally produced VSLS bromocarbons account for almost a quarter of the current stratospheric inorganic bromine and about half of that in the pre-industrial era. Fundamental emissions processes for the VSLS are not well understood, so that we are unsure how emissions might have changed in the past or how they will respond to future climate change. Model calculations do suggest (e.g. Dessens et al., 2009; Hossaini 


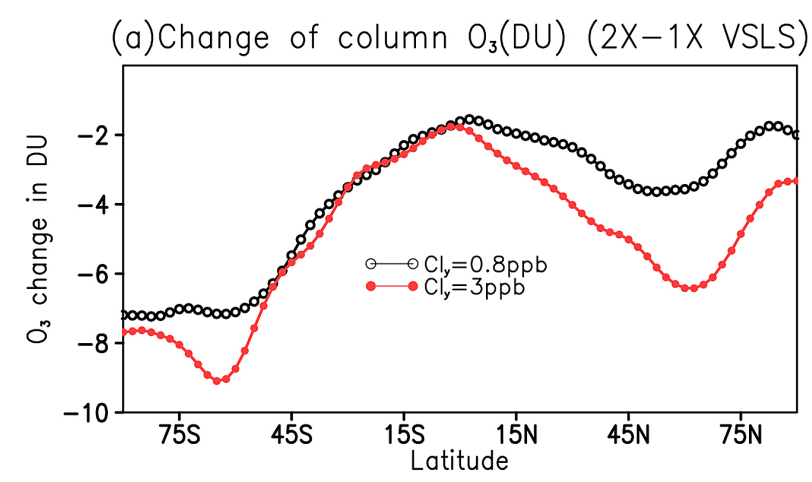

(b) Relative change of column $\mathrm{O}_{3}(2 X-1 X$ VSLS)

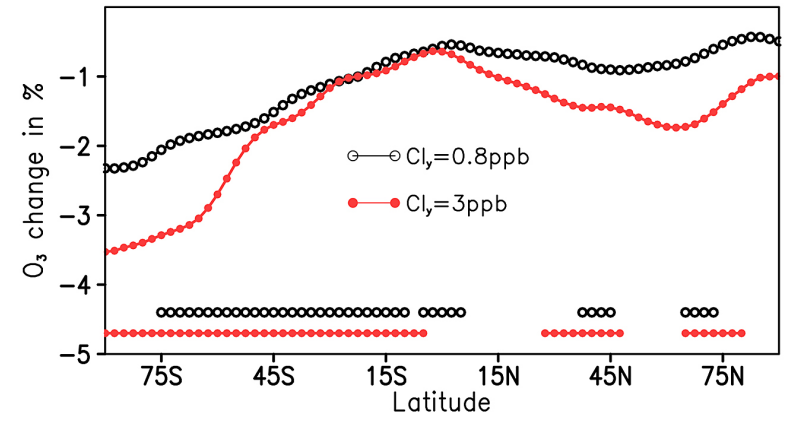

Figure 4. Latitude distributions of annual mean total ozone changes due to a doubling of VSLS. The top panel (a) shows the absolute changes in Dobson units, and the bottom panel (b) shows the relative changes in \%. Each line represents one particular $\mathrm{Cl}_{\mathrm{y}}$ level (black open circles: $\mathrm{Cl}_{y}=0.8 \mathrm{ppb}$; red closed circles: $\mathrm{Cl}_{y}=3 \mathrm{ppb}$ ). Note that we average the ozone difference over the three different $\mathrm{Br}_{\mathrm{y}}$ concentrations for each $\mathrm{Cl}_{\mathrm{y}}$ case. The corresponding horizontal lines indicate where the differences are significant in each of the three pairs of integrations above a confidence level of $99 \%$ as calculated by student's $t$ test.

et al., 2013) that transport to the stratosphere, where these compounds play an important role in regulating lower stratospheric ozone, will increase in the future. To what extent possible increases in VSLS surface emissions or transport to the stratosphere could counteract the effect of halogen reductions under the Montreal Protocol is an important research question, which we have addressed here by using a simple experimental design. In particular, we have asked to what extent the impact of a hypothetical increase in VSLS (we use $5 \mathrm{ppt}$ here) could affect ozone in the lower stratosphere, and how that impact depends on the background concentrations of chlorine and bromine.

Our model experiments indicate that for a $\sim 5 \mathrm{ppt}$ increase in inorganic bromine from VSLS, the depletion of stratospheric ozone can reach up to $10 \%$ in the annual mean in the lowermost stratosphere of the SH polar region, and 4-6\% in the NH. Decreases in the ozone column are largest at high latitudes, are greater for higher chlorine levels, and are dominated by the ozone reductions in the low stratosphere. The SH high latitudes see the largest reductions, with an annual average south of $70^{\circ} \mathrm{S}$ of around $8 \mathrm{DU}$ (Fig. 4a); changes at middle and low latitudes are small.

Ozone losses following an increase in the VSLS burden are highest under a high stratospheric chlorine background, indicating the importance of the inter-halogen reactions. Although bromine plays an important role in destroying atmospheric ozone, chlorine concentrations largely dominate the changes in stratospheric ozone concentrations. Even if bromine levels from natural VSLS were to increase significantly later this century, the concentration of ozone will be dominated by the recovery of anthropogenic chlorine.

It is possible to make a crude estimate of the possible impact on ozone recovery of a hypothetical increase in VSLS bromine. In our calculations, the increase in $\mathrm{Br}_{\mathrm{y}}$ by $5 \mathrm{ppt}$ leads to a reduction in modelled springtime (October) Antarctic ozone of about $9 \mathrm{DU}$ for the $0.8 \mathrm{ppb}$ chlorine case and $\sim 11 \mathrm{DU}$ for the $3 \mathrm{ppb}$ chlorine case. A range of chemistry-climate models reported by the WMO (2011) and Eyring et al. (2010) give a linearly averaged Antarctic springtime (October) ozone recovery rate of about $1.4 \mathrm{DU} \mathrm{yr}^{-1}$ between the years 2025 and 2075 (see Fig. 3.11 and Table 4 of those papers, respectively), so our modelled decreases of 9 and $11 \mathrm{DU}$, due to the additional $5 \mathrm{ppt}$ of bromine under two different chlorine levels, correspond to a delayed recovery of about 6 and 8 years, respectively. We note, in passing, that although Antarctic ozone recovery is predicted consistently by models for the second half of this century, there are large model-model differences.

In these model studies, we have only considered the effect of variations in chlorine and bromine concentrations. We recognise that other changes, including changes in climate and aerosol loading, could also modulate the impact on ozone of changed VSLS emissions. Further studies are required.

Acknowledgements. J. A. Pyle and X. Yang thank the EU for support through SHIVA (SHIVA-226224-EP7-ENV-2008-1) and the ERC for support through the ACCI project (project number 267760). We thank Tara Banerjee for information on changes in the $\mathrm{HO}_{2}+\mathrm{BrO}$ flux with climate change. We thank NCAS-CMS for modelling support. Model integrations have been performed using the UK National Supercomputing Service HECToR.

Edited by: W. T. Sturges

\section{References}

Aschmann, J., Sinnhuber, B.-M., Chipperfield, M. P., and Hossaini, R.: Impact of deep convection and dehydration on bromine loading in the upper troposphere and lower stratosphere, Atmos. Chem. Phys., 11, 2671-2687, doi:10.5194/acp-11-2671-2011, 2011.

Banerjee, A., Archibald, A. T., Maycock, A. C., Telford, P., Abraham, N. L., Yang, X., Braesicke, P., and Pyle, J. A.: Lightning $\mathrm{NO}_{\mathrm{x}}$, a key chemistry-climate interaction: impacts of future climate change and consequences for tropospheric oxidising capac- 
ity, Atmos. Chem. Phys., 14, 9871-9881, doi:10.5194/acp-149871-2014, 2014.

Braesicke, P., Keeble, J., Yang, X., Stiller, G., Kellmann, S., Abraham, N. L., Archibald, A., Telford, P., and Pyle, J. A.: Circulation anomalies in the Southern Hemisphere and ozone changes, Atmos. Chem. Phys., 13, 10677-10688, doi:10.5194/acp-1310677-2013, 2013.

Carpenter, L. J. and Liss, P. S.: On temperate sources of bromoform and other reactive organic bromine gases, J. Geophy. Res., 105, 20539-20547, doi:10.1029/2000JD900242, 2000.

Chipperfield, M. P. and Pyle, J. A.: Model sensitivity studies of Arctic ozone depletion, J. Geophys. Res., 103, 28389-28403, doi:10.1029/98JD01960, 1998.

Dessens, O., Zeng, G., Warwick, N., and Pyle, J.: Short-lived bromine compounds in the lower stratosphere; impact of climate change on ozone, Atmos. Sci. Let., 10, 201-206, doi:10.1002/asl.236, 2009.

Dorf, M., Butz, A., Camy-Peyret, C., Chipperfield, M. P., Kritten, L., and Pfeilsticker, K.: Bromine in the tropical troposphere and stratosphere as derived from balloon-borne $\mathrm{BrO}$ observations, Atmos. Chem. Phys., 8, 7265-7271, doi:10.5194/acp-8-72652008, 2008.

Eyring, V., Cionni, I., Bodeker, G. E., Charlton-Perez, A. J., Kinnison, D. E., Scinocca, J. F., Waugh, D. W., Akiyoshi, H., Bekki, S., Chipperfield, M. P., Dameris, M., Dhomse, S., Frith, S. M., Garny, H., Gettelman, A., Kubin, A., Langematz, U., Mancini, E., Marchand, M., Nakamura, T., Oman, L. D., Pawson, S., Pitari, G., Plummer, D. A., Rozanov, E., Shepherd, T. G., Shibata, K., Tian, W., Braesicke, P., Hardiman, S. C., Lamarque, J. F., Morgenstern, O., Pyle, J. A., Smale, D., and Yamashita, Y.: Multimodel assessment of stratospheric ozone return dates and ozone recovery in CCMVal-2 models, Atmos. Chem. Phys., 10, 94519472, doi:10.5194/acp-10-9451-2010, 2010.

Farman, J. C., Gardiner, B. G., and Shanklin, J. D.: Large losses of total ozone in Antarctica reveal seasonal $\mathrm{ClO}_{\mathrm{x}} / \mathrm{NO}_{\mathrm{x}}$ interaction, Nature, 315, 207-210, doi:10.1038/315207a0, 1985.

Feng, W., Chipperfield, M. P., Dorf, M., Pfeilsticker, K., and Ricaud, P.: Mid-latitude ozone changes: studies with a 3-D CTM forced by ERA-40 analyses, Atmos. Chem. Phys., 7, 2357-2369, doi:10.5194/acp-7-2357-2007, 2007.

Gschwend, P. M., Macfarlane, J. K., and Newman, K. A.: Volatile Halogenated Organic-Compounds Released To Seawater From Temperate Marine Macroalgae, Science, 227, 1033-1035, 1985.

Harper, D. B. and Hamilton, J. T. G.: The global cycles of the naturally-occurring monohalomethanes, in: The Handbook of Environmental Chemistry Vol. 3, Part P, Natural production of organohalogen compounds, edited by: Gribble, G. W., Springer, Berlin, 17-41, 2003.

Hewitt, H. T., Copsey, D., Culverwell, I. D., Harris, C. M., Hill, R. S. R., Keen, A. B., McLaren, A. J., and Hunke, E. C.: Design and implementation of the infrastructure of HadGEM3: the nextgeneration Met Office climate modelling system, Geosci. Model Dev., 4, 223-253, doi:10.5194/gmd-4-223-2011, 2011.

Hossaini, R., Chipperfield, M. P., Feng, W., Breider, T. J., Atlas, E., Montzka, S. A., Miller, B. R., Moore, F., and Elkins, J.: The contribution of natural and anthropogenic very short-lived species to stratospheric bromine, Atmos. Chem. Phys., 12, 371380, doi:10.5194/acp-12-371-2012, 2012a.
Hossaini, R., Chipperfield, M. P., Dhomse, S., Ordonez, C., SaizLopez, A., Abraham, N. L., Archibald, A. T., Braesicke, P., Telford, P. J., Warwick, N. J., Yang, X., and Pyle, J. A.: Modelling future changes to the stratospheric source gas injection of biogenic bromocarbons, Geophys. Res. Lett., 39, L20813, doi:10.1029/2012GL053401, 2012b.

Hossaini, R., Mantle, H., Chipperfield, M. P., Montzka, S. A., Hamer, P., Ziska, F., Quack, B., Krüger, K., Tegtmeier, S., Atlas, E., Sala, S., Engel, A., Bönisch, H., Keber, T., Oram, D., Mills, G., Ordóñez, C., Saiz-Lopez, A., Warwick, N., Liang, Q., Feng, W., Moore, F., Miller, B. R., Marécal, V., Richards, N. A. D., Dorf, M., and Pfeilsticker, K.: Evaluating global emission inventories of biogenic bromocarbons, Atmos. Chem. Phys., 13, 11819-11838, doi:10.5194/acp-13-11819-2013, 2013.

Keppler, F., Eiden, R., Niedan, V., Pracht, J., and Schöler, H. F.: Halocarbons produced by natural oxidation processes during degradation of organic matter, Nature, 403, 298-301, 2000.

Ko, M. K. W., Sze, N.-D., Scott, C. J., and Weisenstein, D. K.: On the relation between stratospheric chlorine/bromine loading and short-lived tropospheric source gases, J. Geophys. Res., 102, 25507-25517, 1997.

Liang, Q., Stolarski, R. S., Kawa, S. R., Nielsen, J. E., Douglass, A. R., Rodriguez, J. M., Blake, D. R., Atlas, E. L., and Ott, L. E.: Finding the missing stratospheric Bry: a global modeling study of $\mathrm{CHBr}_{3}$ and $\mathrm{CH}_{2} \mathrm{Br}_{2}$, Atmos. Chem. Phys., 10, 2269-2286, doi:10.5194/acp-10-2269-2010, 2010.

McElroy, M. B., Salawitch R. J., Wofsy, S. C., and Logan, J. A.: Reductions of Antarctic ozone due to synergistic interactions of chlorine and bromine, Nature, 321, 759-762, 1986.

Molina, M. J. and Rowland, F. S.: Stratospheric Sink for Chlorofluoromethanes: Chlorine Atom-Catalysed Destruction of Ozone, Nature, 249, 810-812, doi:10.1038/249810a0, 1974.

Montzka, S. A. and Reimann, S. (Lead Authors), Engel, A., Krüger, K., O’Doherty, S., Sturges, W. T., Blake, D., Dorf, M., Fraser, P., Froidevaux, L., Jucks, K., Kreher, K., Kurylo, M. J., Mellouki, A., Miller, J., Nielsen, O.-J., Orkin, V. L., Prinn, R.G., Rhew, R., Santee M. L., and Verdonik, D.: Ozone-depleting substances (ODSs) and related chemicals, in: Scientific Assessment of Ozone Depletion: 2010, Global Ozone Research and Monitoring Project, edited by: World Meteorological Organization, Report No. 52, Chapt. 1, Geneva, Switzerland, 2011.

Morgenstern, O., Braesicke, P., O’Connor, F. M., Bushell, A. C., Johnson, C. E., Osprey, S. M., and Pyle, J. A.: Evaluation of the new UKCA climate-composition model - Part 1: The stratosphere, Geosci. Model Dev., 2, 43-57, doi:10.5194/gmd-2-432009, 2009.

O'Connor, F. M., Johnson, C. E., Morgenstern, O., Abraham, N. L., Braesicke, P., Dalvi, M., Folberth, G. A., Sanderson, M. G., Telford, P. J., Voulgarakis, A., Young, P. J., Zeng, G., Collins, W. J., and Pyle, J. A.: Evaluation of the new UKCA climatecomposition model - Part 2: The Troposphere, Geosci. Model Dev., 7, 41-91, doi:10.5194/gmd-7-41-2014, 2014.

Ordóñez, C., Lamarque, J.-F., Tilmes, S., Kinnison, D. E., Atlas, E. L., Blake, D. R., Sousa Santos, G., Brasseur, G., and Saiz-Lopez, A.: Bromine and iodine chemistry in a global chemistry-climate model: description and evaluation of very short-lived oceanic sources, Atmos. Chem. Phys., 12, 1423-1447, doi:10.5194/acp12-1423-2012, 2012. 
Pyle, J. A., Ashfold, M. J., Harris, N. R. P., Robinson, A. D., Warwick, N. J., Carver, G. D., Gostlow, B., O’Brien, L. M., Manning, A. J., Phang, S. M., Yong, S. E., Leong, K. P., Ung, E. H., and Ong, S.: Bromoform in the tropical boundary layer of the Maritime Continent during OP3, Atmos. Chem. Phys., 11, 529-542, doi:10.5194/acp-11-529-2011, 2011.

Quack B. and Wallace, D. W. R.: Air-sea flux of bromoform: controls, rates and implications, Global Biogeochem. Cycles, 17, 1023, doi:10.1029/2002GB001890, 2003.

Salawitch, R. J.: Atmospheric chemistry - Biogenic bromine, Nature, 439, 275-277, 2006.

Salawitch, R. J., Wofsy, S. C., and McElroy, M. B.: Chemistry of $\mathrm{OClO}$ in the Antarctic stratosphere: Implications for bromine, Planet. Space Sci.,36, 213-224, doi:10.1016/00320633(88)90058-X, 1988.

Salawitch, R. J., Weisenstein, D. K., Kovalenko, L. J., Sioris, C. E., Wennberg, P. O., Chance, K., Ko, M. K. W., and McLinden, C. A.: Sensitivity of ozone to bromine in the lower stratosphere, Geophys. Res. Lett., 32, L05811, doi:10.1029/2004GL021504, 2005.

Salawitch, R. J., Canty, T., Kurosu, T., Chance, K., Liang, Q., da Silva, A., Pawson, S., Nielsen, J. E., Rodriguez, J. M., Bhartia, P. K., Liu, X., Huey, L. G., Liao, J., Stickel, R. E., Tanner, D. J., Dibb, J. E., Simpson, W. R., Donohoue, D., Weinheimer, A., Flocke, F., Knapp, D., Montzka, D., Neuman, J. A., Nowak, J. B., Ryerson, T. B., Oltmans, S., Blake, D. R., Atlas, E. L., Kinnison, D. E., Tilmes, S., Pan, L. L., Hendrick, F., Van Roozendael, M., Kreher, K., Johnston, P. V., Gao, R. S., Johnson, B., Bui, T. P., Chen, G., Pierce, R. B., Crawford, J. H., and Jacob, D. J.: A new interpretation of total column $\mathrm{BrO}$ during Arctic spring, Geophys. Res. Lett., 37, L21805, doi:10.1029/2010g1043798, 2010.

Saltzman, E. S., Aydin, M., Tatum, C., and Williams, M. B.: 2000-year record of atmospheric methyl bromide from a South Pole ice core, J. Geophys. Res., 113, D05304, doi:10.1029/2007JD008919, 2008.

Schofield, R., Fueglistaler, S., Wohltmann, I., and Rex, M.: Sensitivity of stratospheric $\mathrm{Br}_{y}$ to uncertainties in very short lived substance emissions and atmospheric transport, Atmos. Chem. Phys., 11, 1379-1392, doi:10.5194/acp-11-1379-2011, 2011.

Sinnhuber, B.-M., Sheode, N., Sinnhuber, M., Chipperfield, M. P., and Feng, W.: The contribution of anthropogenic bromine emissions to past stratospheric ozone trends: a modelling study, Atmos. Chem. Phys., 9, 2863-2871, doi:10.5194/acp-9-2863-2009, 2009.

Solomon, S.: Stratospheric ozone depletion: A review of concepts and history, Rev. Geophys., 37, 275-316, doi:10.1029/1999RG900008, 1999.
Stachnik, R. A., Millán, L., Jarnot, R., Monroe, R., McLinden, C., Kühl, S., Pukíte, J., Shiotani, M., Suzuki, M., Kasai, Y., Goutail, F., Pommereau, J. P., Dorf, M., and Pfeilsticker, K.: Stratospheric BrO abundance measured by a balloon-borne submillimeterwave radiometer, Atmos. Chem. Phys., 13, 3307-3319, doi:10.5194/acp-13-3307-2013, 2013.

Sturges, W., Oram, D., Carpenter, L., Penkett, S., and Engel, A.: Bromoform as a source of stratospheric bromine, Geophys. Res. Lett., 27, 2081-2084, doi:10.1029/2000GL011444, 2000.

Tegtmeier, S., Krüger, K., Quack, B., Atlas, E. L., Pisso, I., Stohl, A., and Yang, X.: Emission and transport of bromocarbons: from the West Pacific ocean into the stratosphere, Atmos. Chem. Phys., 12, 10633-10648, doi:10.5194/acp-12-10633-2012, 2012.

Warwick, N. J., Pyle, J. A., Carver, G. D., Yang, X., Savage, N. H., O'Connor, F. M., and Cox, R. A.: Global modeling of biogenic bromocarbons, J. Geophys. Res., 111, D24305, doi:10.1029/2006JD007264, 2006.

WMO (World Meteorological Organization), Scientific Assessment of Ozone Depletion: 2010, Global Ozone Research and Monitoring Project-Report No. 52, 516 pp., Geneva, Switzerland, 2011.

Wofsy, S., McElroy, M., and Yung, Y.: Chemistry of atmospheric bromine, Geophys. Res. Lett., 2, 215-218, doi:10.1029/GL002i006p00215, 1975.

Yang, X., Cox, R. A., Warwick, N. J., Pyle, J. A., Carver, G. D., O'Connor, F. M., and Savage, N. H.: Tropospheric bromine chemistry and its impacts on ozone: A model study, J. Geophys. Res., 110, D23311, doi:10.1029/2005JD006244, 2005.

Yang, X., Pyle, J. A., Cox, R. A., Theys, N., and Van Roozendael, M.: Snow-sourced bromine and its implications for polar tropospheric ozone, Atmos. Chem. Phys., 10, 7763-7773, doi:10.5194/acp-10-7763-2010, 2010.

Yokouchi, Y., Hasebe, F., Fujiwara, M., Takashima, H., Shiotani, M., Nishi, N., Kanaya, Y., Hashimoto, S., Fraser, P., ToomSauntry, D., Mukai, H., and Nojiri, Y.: Correlations and emission ratios among bromoform, dibromochloromethane, and dibromomethane in the atmosphere, J. Geophys. Res.-Atmos., 110, D23309, doi:10.1029/2005JD006303, 2005.

Ziska, F., Quack, B., Abrahamsson, K., Archer, S. D., Atlas, E., Bell, T., Butler, J. H., Carpenter, L. J., Jones, C. E., Harris, N. R. P., Hepach, H., Heumann, K. G., Hughes, C., Kuss, J., Krüger, K., Liss, P., Moore, R. M., Orlikowska, A., Raimund, S., Reeves, C. E., Reifenhäuser, W., Robinson, A. D., Schall, C., Tanhua, T., Tegtmeier, S., Turner, S., Wang, L., Wallace, D., Williams, J., Yamamoto, H., Yvon-Lewis, S., and Yokouchi, Y.: Global sea-toair flux climatology for bromoform, dibromomethane and methyl iodide, Atmos. Chem. Phys., 13, 8915-8934, doi:10.5194/acp13-8915-2013, 2013. 